\title{
Epoxy resin compositions containing liquid phosphorus flame retardants used in infusion technology (Rapid communication)
}

\author{
Rafał Oliwa ${ }^{1)}$ \\ DOI: dx.doi.org/10.14314/polimery.2020.7.12
}

\begin{abstract}
This study investigates the impact of the type and amount of liquid phosphorus flame retardant additive on the flammability and mechanical properties of epoxy compositions dedicated to the infusion process. To this purpose, epoxy resin (EP) compositions containing 10 and $20 \mathrm{wt} \%$ of liquid ammonium polyphosphate (APPL) and dimethyl methylphosphonate (DMMP) were obtained. Mechanical properties and flame resistance of obtained epoxy compositions were determined in terms of their use as a matrix in laminate infusion technology. Based on the results obtained, it was found, that the flame resistance increases, while the mechanical properties decreases with flame retardant loading. The best flame resistance results were obtained for a composite containing $20 \mathrm{wt} \%$ APPL: limiting oxygen index $L O I=23.9 \%$ instead of $19.8 \%$ - EP, peak of heat release rate $p H R R=427.3 \mathrm{~kW} / \mathrm{m}^{2}$ instead of $1046.3 \mathrm{~kW} / \mathrm{m}^{2}-\mathrm{EP}$.
\end{abstract}

Keywords: composites, epoxy resin, infusion, liquid flame retardants.

\section{Kompozycje żywic epoksydowych z dodatkiem ciekłych uniepalniaczy fosforowych stosowane $w$ technologii infuzji}

\begin{abstract}
Streszczenie: Zbadano wpływ rodzaju i ilości dodatku ciekłych uniepalniaczy fosforowych na palność i właściwości mechaniczne kompozycji epoksydowych przeznaczonych do zastosowania w procesie infuzji. Wytworzono kompozycje żywicy epoksydowej (EP) zawierające 10 i 20\% mas. ciekłego poli(fosforanu amonu) (APPL) oraz metylofosfonianu dimetylu (DMMP). Określono właściwości mechaniczne oraz odporność na płomień otrzymanych kompozycji epoksydowych w kontekście ich zastosowania $\mathrm{w}$ charakterze osnowy $\mathrm{w}$ technologii infuzji laminatów. Na podstawie uzyskanych wyników stwierdzono, że wraz ze zwiększaniem zawartości uniepalniaczy zwiększała się odporność na płomień, natomiast pogarszały się właściwości mechaniczne kompozycji. Najlepszą odporność na płomień wykazywał kompozyt z udziałem $20 \%$ mas. APPL: graniczny indeks tlenowy $L O I=23.9 \%$ (w odniesieniu do wartości LOI żywicy epoksydowej 19.8\%) oraz maksymalna szybkość uwalniania ciepła $p H R R=427.3 \mathrm{~kW} / \mathrm{m}^{2}$ (w porównaniu do $p H R R$ żywicy $1046.3 \mathrm{~kW} / \mathrm{m}^{2}$ ).
\end{abstract}

Słowa kluczowe: kompozyty, żywica epoksydowa, infuzja, ciekłe uniepalniacze.

In recent years, epoxy resins have found use as construction materials in the automotive and aerospace industries. Due to good performance and low viscosity, they are often used to obtain composites using infusion technology. Therefore, to increase the potential use of epoxy resins, they are modified through the use of effective flame retardants, which include compounds containing phosphorus, silicon, bromine or nitrogen. As phosphorus based flame retardants, to reduce the flammability of epoxy resins, reactive substances are used,

\footnotetext{
1) Rzeszow University of Technology, Department of Polymer Composites, al. Powstańców Warszawy 6, 35-959 Rzeszów, Poland, e-mail: oliwa@prz.edu.pl
}

which are incorporated into the structure of the epoxy network [1, 2]. However, the presence of -P-O- groups in the main or side chain of epoxy resin significantly reduces the thermal stability of composites in the initial stages of decomposition (by up to $150^{\circ} \mathrm{C}$ ) and causes a decrease in the glass transition temperature of composites by up to $90^{\circ} \mathrm{C}$ compared to commercial epoxies [3]. Until recently, resins derived from tetrabromodian and epichlorohydrin remained among the many different products on the market. Currently due to the tendency to exclude bromine compounds as potentially harmful to the environment, epoxy resin with the addition of phosphorus flame retardants are starting to compete with them [4, 5]. Undoubtedly, the addition of reactive compounds improves flame resistance, but their 
synthesis and method of application makes their use in processing very difficult. Phosphorus additive flame retardants in the form of phosphates, phosphinates or phosphine oxides are also effective compounds improving flame resistance of epoxy composites. Their effectiveness depends mainly on the proportions used and appropriate mixing in the epoxy matrix. However, the main disadvantage of this type of flame retardants, limiting their application as a laminate matrix in pressurevacuum technologies such as infusion or RTM (Resin Transfer Molding), is a significant increase in the viscosity of epoxy compositions. Additive liquid phosphorus flame retardants can be an alternative to additive powder flame retardants. Dimethyl methylphosphonate (DMMP) is known as an effective synergistic agent in reducing the flammability of polyester resins [6], epoxy resin [7] and polyurethane foam [8]. However, there is no information on the effect of the addition of liquid additive flame retardants such as DMMP and APPL (ammonium polyphosphate), on the flame resistance and mechanical properties of epoxy resins.

Therefore, the purpose of this work is to investigate the effect of the amount and type of phosphorus based liquid flame retardants on the flammability and mechanical properties of epoxy composites in the context of their use as a matrix of laminates obtained by pressure or vacuum methods. The results presented in the article are an extension of research on composites with increased flame resistance using halogen-free flame retardants.

\section{EXPERIMENTAL PART}

\section{Materials}

The following materials were used in this study:

- Epoxy resin Epidian ${ }^{\circledast} 624$ - epoxy resin containing mostly diglycidyl ether of bisphenol A (EP) and the curing agent triethylenetetramine (Z1), both commercial grade products of Ciech-Sarzyna Plant, Poland.

- Halogen-free liquid flame retardants: ammonium polyphosphate (APPL) and dimethyl methylphosphonate (DMMP), produced by WTH (GmbH, Germany)

\section{Preparation of test samples}

A flame retardant was added to the epoxy resin (Epidian ${ }^{\circledR} 624$ ) in amounts of 10 or 20 wt \% and mixed for 10 minutes using a high speed turbine homogenizer (Dispermat CN40 produced by VMA-Getzmann, Gmbh). The stirrer speed was about $1500 \mathrm{rpm}$. Then, the compositions were degassed using a VAKUUM UHG 400 chamber (Schuechl, Germany). Then, after adding $12 \mathrm{wt} \%$ hardener, the compositions were cast into silicone molds prepared in accordance with ISO 527-1:1998. The samples were cured at room temperature for $24 \mathrm{~h}$ and then at $100^{\circ} \mathrm{C}$ for $6 \mathrm{~h}$. After two days, the fittings were tested in accordance with the relevant standards.

\section{Methods of testing}

- The bending strength was determined in accordance with PN-EN ISO 178 using the INSTRON 5967 testing machine. The bending speed was $2 \mathrm{~mm} / \mathrm{min}$. The strength test was performed using the three-point bending method for a support spacing of $64 \mathrm{~mm}$.

- Tensile strength was determined in accordance with ISO 527-1:1998 using the same tensile machine equipped with a video extensometer. Elongation speed was $2 \mathrm{~mm} / \mathrm{min}$.

- Rockwell hardness was determined using a ZWICK 3106 hardness tester in accordance with EN 10109-1. An indenter load of $358 \mathrm{~N}$ was used. The final result was an arithmetic mean of at least 10 measurements.

- Charpy impact strength was determined in accordance with PN-EN ISO 179-1 with Ceast 9050 Impact Pendulum (Italy), using hammer impact energy of $1 \mathrm{~J}$.

- Limiting oxygen index $(\mathrm{LOI})$ was determined according to the standard EN ISO 4589-1 at room temperature using an instrument of Fire Testing Technology Ltd. (United Kingdom).

- The UL-94 flame tests were carried out in a chamber produced by FTT Ltd (UK). The measurements were made according to the UL-94 test standard with horizontal sample beam position and a methane fed burner of $20 \mathrm{~mm}$ height.

- The maximum heat release rate $\left(p H R R\right.$ in $\left.\mathrm{kW} / \mathrm{m}^{2}\right)$ during sample combustion and other parameters characterizing flammability were evaluated in composite plates, $100 \times 100 \times 2\left(\mathrm{~mm}^{3}\right)$ in size, using a Mass Loss Calorimeter (MLC) from FTT Ltd, according to ISO 13927, by applying a heat flux of $50 \mathrm{~kW} / \mathrm{m}^{2}$ and the distance from the ignition source of $25 \mathrm{~mm}$.

\section{RESULTS AND DISCUSSION}

Based on the results summarized in Table 1, it was found that with increasing content of liquid flame retardants, the mechanical properties of epoxy composites decrease. The flexural strength and flexural modulus of composites containing $10 \mathrm{wt} \%$ of APPL and DMMP were reduced by an average of 18 and $12 \%$, compared to the unmodified resin. Increasing the content of flame retardants to $20 \mathrm{wt} \%$ caused even a double decrease of these parameters. Similar relationships were observed in the case of tensile strength and Young's modulus. Only the value of the tensile strength of composites containing $10 \mathrm{wt} \%$ flame retardants slightly decreased, by an average of $7 \%$, compared to the reference sample. However, the content of $20 \mathrm{wt} \%$ has already caused a significant decrease of this parameter, by 47 and $42 \%$, for a composite containing ammonium polyphosphate and dimethyl methylphosphonate, respectively. In turn, the Young's modulus decreased by 1.54 and $1.37 \mathrm{GPa}$, respectively, in relation to epoxy resin (Young's modulus $=2.52 \mathrm{GPa}$ ). In the case of Charpy impact tests, a clear, $50 \%$, decrease in 
T a b l e 1. Mechanical properties of epoxy resin and epoxy composites with liquid flame retardants

\begin{tabular}{c|c|c|c|c|c|c}
\hline $\begin{array}{c}\text { Symbol of } \\
\text { sample }\end{array}$ & $\begin{array}{c}\text { Ultimate flexural } \\
\text { strength } \\
\mathrm{MPa}\end{array}$ & $\begin{array}{c}\text { Flexural } \\
\text { modulus } \\
\mathrm{GPa}\end{array}$ & $\begin{array}{c}\text { Ultimate tensile } \\
\text { strength } \\
\mathrm{MPa}\end{array}$ & $\begin{array}{c}\text { Young modulus } \\
\mathrm{GPa}\end{array}$ & $\begin{array}{c}\text { Charpy impact } \\
\mathrm{kJ} / \mathrm{m}^{2}\end{array}$ & $\begin{array}{c}\text { Rockwell } \\
\text { hardness } \\
\mathrm{MPa}\end{array}$ \\
\hline EP & $89.01 \pm 7.2$ & $2.22 \pm 0.35$ & $22.6 \pm 2.1$ & $2.52 \pm 0.40$ & $11.3 \pm 1.2$ & $127.2 \pm 3.8$ \\
EP10APPL & $73.4 \pm 6.7$ & $1.98 \pm 0.30$ & $20.8 \pm 2.6$ & $1.88 \pm 0.15$ & $9.0 \pm 2.1$ & $93.1 \pm 3.5$ \\
EP20APPL & $44.9 \pm 2.6$ & $1.05 \pm 0.41$ & $11.9 \pm 3.0$ & $0.98 \pm 0.31$ & $5.8 \pm 1.5$ & $69.0 \pm 2.5$ \\
EP10DMMP & $70.6 \pm 3.9$ & $1.91 \pm 1.31$ & $21.2 \pm 3.2$ & $1.84 \pm 0,20$ & $9.1 \pm 1.6$ & $117.2 \pm 1.9$ \\
EP20DMMP & $32.8 \pm 2.6$ & $0.92 \pm 0.17$ & $13.0 \pm 1.6$ & $1.15 \pm 0.11$ & $5.4 \pm 1.2$ & $51.2 \pm 2.7$ \\
\hline
\end{tabular}

\pm- standard deviation

$\mathrm{T}$ a b 1 e 2. The results of flammability tests of epoxy resin and epoxy composites with liquid flame retardants

\begin{tabular}{c|c|c|c|c|c|c|c|c}
\hline $\begin{array}{c}\text { Symbol } \\
\text { of sample }\end{array}$ & $\begin{array}{c}\text { TTI } \\
\mathrm{s}\end{array}$ & $\begin{array}{c}\mathrm{pHRR} \\
\mathrm{kW} / \mathrm{m}^{2}\end{array}$ & $\begin{array}{c}\mathrm{THR} \\
\mathrm{MJ} / \mathrm{m}^{2}\end{array}$ & $\begin{array}{c}E H C \\
\mathrm{MJ} / \mathrm{kg}\end{array}$ & $\begin{array}{c}P M L \\
\%\end{array}$ & $\begin{array}{c}\text { Vertical } \\
\text { burning rate } \\
\mathrm{mm} / \mathrm{min}\end{array}$ & $\begin{array}{c}\text { UL-94 class } \\
\%\end{array}$ \\
\hline EP & 31 & 1046.3 & 57.4 & 64.3 & 94.2 & 32 & HB 40 & 19.8 \\
EP10APPL & 29 & 548.2 & 48.9 & 54.8 & 86.1 & - & HB $40 \mathrm{~b}$ & 21.8 \\
EP20APPL & 25 & 427.3 & 42.6 & 50.4 & 83.6 & - & HB $40 \mathrm{~b}$ & 23.9 \\
EP10DMMP & 27 & 605.7 & 50.5 & 57.6 & 82.4 & 24 & HB 40 & 21.9 \\
EP20DMMP & 21 & 515.7 & 40.1 & 56.3 & 78.8 & 12 & HB 40 & 23.6 \\
\hline
\end{tabular}

TTI - time to ignition, $p H R R$ - peak heat release rate, THR - total heat released, EHC - effective heat of combustion, $P M L-$ percent mass loss, $L O I$ - limiting oxygen index

this parameter was observed for composites containing 20 wt \% flame retardants (Table 1). As could be expected, Rockwell hardness also significantly deteriorated in line with the relationship observed during impact tests. In short, the liquid flame retardants significantly reduced the mechanical properties of the epoxy composites. Decrease in the mechanical properties is greater than the our results obtained for glass fiber reinforced composites [9] as well as literature data where ammonium polyphosphate was used in powder form [10, 11]. What's more, the Rajaei [10] and Lim [12] teams achieved an increase in the flexural and Young's modulus of epoxy compositions containing solid ammonium polyphosphate (APP).

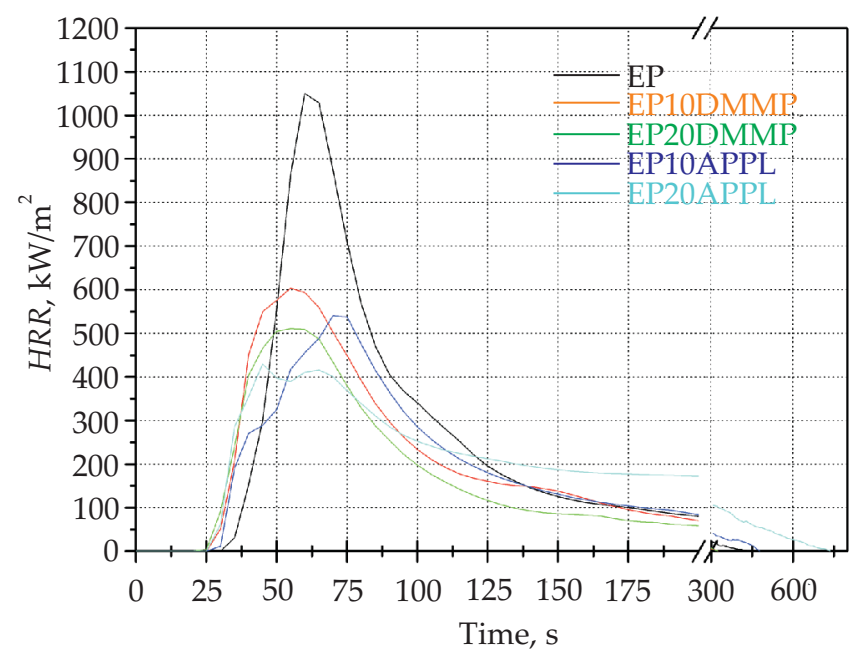

Fig. 1. Heat release rate $(H R R)$ curves as a function of time during flammability tests performed in the mass loss calorimeter of unfilled epoxy resin and epoxy composites
The results of tests for determining the flammability of epoxy composites using a mass loss calorimeter are given in Table 2. The results are the arithmetic mean of three measurements for each composite. In turn, Fig. 1 shows representative curves of the dependence of heat release rate as a function of time recorded during the test.

Based on the Fig. 1, it was found that the addition of phosphorus flame retardants changes the burning process of epoxy composites compared to unmodified epoxy resin. In the case of unfilled epoxy resin, the ignition time was $31 \mathrm{~s}$, followed by a sharp and rapid increase in heat release, as a result of which the recorded average $p H R R$ value was $1046 \mathrm{~kW} / \mathrm{m}^{2}$. In turn, the addition of flame retardants caused faster ignition of the sample, which is associated with their faster distribution [13] and a significant, by half, reduction of the maximum heat release rate. With APPL loading, the maximum heat release rate decreased by 48 and 59\%, respectively, compared to the unmodified resin, while the composite containing DMMP stood out for the reduction in the $p H R R$ value, by 42 and $50 \%$. The addition of 10 and $20 \mathrm{wt} \%$ APPL causes a decrease in THR by 15 and $26 \%$, compared to the unfilled resin, and a percentage mass loss of 83.6 and $86.1 \%$. In turn, composites with 20 wt \% DMMP were characterized by the largest reduction of THR by 30\%, compared to the reference sample and the lowest mass loss (PML) of 78.8\%. The analysis of the reduction of the EHC value and the increase in residue of composites containing flame retardants, carried out in accordance with our previous works [5] and literature data [14] indicates that the gas-phase effect plays a major role in the reduction of THR as confirmed by the calculated values $(83.5,78.4,70.0$ and $73.3 \%$ for $10 \%$ 
APPL, 10\% DMMP, 20\% APPL, 20\% DMMP, respectively). In turn, the decrease in $p H R R$ was also determined by the protective barrier effect. Among the flame retardants used, the calculated additional protection effect of the char layer was larger for composites with the addition of APPL and was 37 and $41 \%$, which showed a intumescence of char during the test.

The results obtained from the UL-94 and limiting oxygen index tests are shown in Table 2. The flammability class for unfilled epoxy resin was defined as HB 40, which means that the burning rate of the sample did not exceed $40 \mathrm{~mm} / \mathrm{min}$ at a distance of $75 \mathrm{~mm}$. The burning rate for this sample was the highest and amounted to $32 \mathrm{~mm} / \mathrm{min}$. Unexpectedly, the addition of flame retardants slightly changed the flame resistance in the UL-94 test, because regardless of the type and amount of flame-retardant additives applied, the composites also achieved HB 40 flammability class, which is a much weaker result compared to composites filled with standard ammonium polyphosphate - the addition in the range 10-15 wt \% allow to obtain V0 flammability class of composites $[15,16]$. Only the burning rate changed, which for the composite with 10 and 20 wt \% DMMP was 24 and $12 \mathrm{~mm} / \mathrm{min}$, respectively. On the other hand, the composite with APPL was impossible to measure because the flame front didn't reach the $75 \mathrm{~mm}$ distance. Also much worse results compared to the literature data [17] were obtained in the case of the oxygen index, which reached the value of about 21.8 and $23.9 \%$ for composites containing 10 and $20 \mathrm{wt} \%$ of flame retardants, respectively.

\section{SUMMARY}

The paper presents the results concerning the influence of the application of liquid phosphorus flame retardants on utility properties of epoxy composites. For this purpose, liquid ammonium polyphosphate and dimethyl methylphosphonate were used. The obtained results indicate that the addition of liquid flame retardants in an amount of up to $20 \mathrm{wt} \%$ significantly reduces the mechanical properties compared to the addition of standard flame retardants in the form of powder. Also the degree of flame retardancy turned out to be much lower as the composites containing $20 \mathrm{wt} \%$ of flame-retardant additives were characterized by HB 40 flammability class according to UL-94 and an LOI of $23.8 \%$. In turn, tests in a mass loss calorimeter showed a significant reduction, by more than $50 \%$, in the value of the maximum heat release rate, compared to the reference sample, which was associated with the activity of flame retardants in the gas phase and, to a lesser extent, the additional protective barrier effect.

\section{REFERENCES}

[1] Chi Z., Guo Z., Xu Z. et al.: Polymer Degradation and Stability 2020, 176, 109151.

http://dx.doi.org/10.1016/j.polymdegradstab.2020.109151

[2] Back J-H., Baek D., Kim T. et al.: International Journal of Adhesion and Adhesives 2020, 100, 102601. https://doi.org/10.1016/j.ijadhadh.2020.102601

[3] Jeng R.-J., Shau S.-M., Lin J.-J. et al.: European Polymer Journal 2002, 38, 683.

http://dx.doi.org/10.1016/S0014-3057(01)00246-4

[4] Oliwa R., Oleksy M., Oliwa J. et al.: Polimery 2019, 64, 290.

http://dx.doi.org/10.14314/polimery.2019.4.7

[5] Oliwa R., Oleksy M., Czech-Polak J. et al.: Journal of Fire Sciences 2019, 37, 155.

http://dx.doi.org/10.1177/0734904119831211

[6] Chen Z., Jiang M., Zhang Q.et al.: International Journal of Polymer Analysis and Characterization 2017, 22, 509. https://doi.org/10.1080/1023666X.2017.1331393

[7] Zheng T., Ni X.: RSC Advances 2016, 6, 57122. https://doi.org/10.1039/C6RA08178A

[8] Xu Z., Duan L., Hou Y. et al.: Composites Part A: Applied Science and Manufacturing 2020, 131, 105815. https://doi.org/10.1016/j.compositesa.2020.105815

[9] Oliwa R., Bulanda K., Oleksy M. et al.: Polimery 2020, $65,387$. http://dx.doi.org/10.14314/polimery.2020.5.7

[10] Rajaei M., Wang D.-Y., Bhattacharyya D.: Composites Part B: Engineering 2017, 113, 381.

http://dx.doi.org/10.1016/j.compositesb.2017.01.039

[11] Szolnoki B., Toldy A., Konrád P. et al.: Periodica Polytechnica Chemical Engineering 2013, 57, 85. http://dx.doi.org/10.3311/PPch.2175

[12] Lim Patrick W.K., Mariatti M., Chow W.S., Mar K.T.: Composites Part B: Engineering 2012, 43, 124. http://dx.doi.org/10.1016/j.compositesb.2011.11.013

[13] Wu K., Zhang Y.-K., Zhang K. et al.:. Journal of Analytical and Applied Pyrolysis 2012, 94, 196. http://dx.doi.org/10.1016/j.jaap.2011.12.009

[14] Schartel B., Hull T.R.: Fire and Materials 2007, 31, 327. http://dx.doi.org/10.1002/fam.949

[15] Zhao C., Li Y., Xing Y. et al.: Journal of Applied Polymer Science 2014, 131, 40218. http://dx.doi.org/10.1002/app.40218

[16] Oliwa R., Heneczkowski M. Oleksy M., Galina H.: Composites Part B: Engineering 2016, 95, 1. http://dx.doi.org/10.1016/j.compositesb.2016.03.074

[17] Liu L., Zhang Y., Li L., Wang Z.: Polymers for Advanced Technologies 2011, 22, 2403. http:/dx.doi.org/10.1002/pat.1776

Received 29 IV 2020. 